\title{
PENGUNGKAPAN CSR DAN CERMINAN ABNORMAL RETURN PERUSAHAAN
}

\author{
Desmon Daniel \\ PPM School of Management \\ desmonsaragi@gmail.com \\ Martdian Ratnasari \\ PPM School of Management \\ martdianratnasari@gmail.com
}

\begin{abstract}
Abstrak
Kajian terkait corporate social responsibility (CSR) berkembang pesat seiring dengan dukungan pemerintahan dalam menciptakan lingkungan bisnis yang bersaing. Dukungan pemerintahan tercermin dalam Undang-Undang No.40 Tahun 2007 tentang Perseroan Terbatas (pasal 74 ayat 1a). Tujuan penelitian ini dilakukan adalah untuk mengetahui pengaruh pengungkapan CSR dan cerminannya pada abnormal return perusahaan di industri pertambangan batu bara. Dalam penelitian ini pengungkapan CSR dihitung menggunakan Global Reporting Initiative (GRI) dengan 78 item di dalamnya dan abnormal return dihitung menggunakan adjusted model secara kumulatif selama periode jendela yang digunakan yakni 10 hari. Hasil penelitian ini menunjukan bahwa pengungkapan CSR mempengaruhi keputusan investor dalam berinvestasi, yang tercermin dengan adanya abnormal return yang dihasilkan. Hal ini diharapkan dapat meningkatkan motivasi perusahaan untuk mengungkapkan CSR dan menjadi lebih sadar akan pentingnya isu-isu CSR untuk memaksimalkan dampak positif dan meminimalkan dampak negatif dari kegiatan bisnis perusahaan.
\end{abstract}

Kata Kunci: Pengungkapan corporate social responsibility, abnormal return, dan perusahaan batu bara

\begin{abstract}
Studies related to corporate social responsibility (CSR) are growing rapidly along with government support in creating a competitive business environment. Government support is reflected in Law No.40 of 2007 concerning Limited Liability Companies (article 74 paragraph 1a). The purpose of this research is to find out whether there is an effect of CSR disclosure on the company's abnormal return in the coal mining industry. In this study, disclosure of CSR is calculated using the Global Reporting Initiative (GRI) with 78 items in it and abnormal returns are calculated using the cumulative adjusted model during the window period used which is 10 days. The population in this study were all 22 coal mining companies listed on the Indonesia Stock Exchange during the 2013-2017 period. The results of this study indicate that CSR disclosure has a positive effect on abnormal returns, which means that investors consider CSR information in making investment decisions. This is expected to increase the motivation of companies to disclose CSR and become more aware of the importance of CSR issues to maximize positive impacts and minimize the negative impact of the company's business activities.
\end{abstract}

Keyword: Disclosure of corporate social responsibility, abnormal return, coal companies 


\section{PENDAHULUAN}

Bertambahnya jumlah dan intensitas produksi tanpa memperhatikan keberlanjutan lingkungan hidup menyebabkan dampak serius di masa depan. Banjir, tanah longsor, dan kelangkaan adalah sebagian kecil dari dampak kerusakan lingkungan yang disebabkan oleh perkembangan industri. Dampak tersebut juga mengganggu kehidupan manusia sebagai bagian dari lingkungan hidup. Maka dari itu kesadaran atas kelestarian lingkungan kembali menjadi sorotan penting dalam kehidupan. Pada akhirnya kerusakan lingkungan akibat perkembangan industri dapat mempengaruhi pihak eksternal dalam menilai suatu perusahaan. Isu mengenai pencemaran lingkungan oleh dunia industri menjadi perhatian khusus Kementerian Lingkungan Hidup. Dalam laporannya, Kementerian Lingkungan Hidup mengumumkan bahwa setidaknya ada 21 perusahaan yang masuk dalam "Daftar Hitam" pencemaran lingkungan selama tahun 2014-2015 (CNN Indonesia, 21 Desember 2015). Pelanggaran yang dilakukan oleh ke-21 perusahaan tersebut mencakup tidak lolosnya dokumen lingkungan, pencemaran air, pencemaran udara, dan perusakan lahan sekitar.

Corporate social responsibility (CSR) adalah salah satu bentuk tanggung jawab dari perusahaan atas kegiatan usahanya yang berdampak kepada lingkungan hidup. Menurut The World Business Council for Sustainable Development secara sederhana CSR juga dapat dikatakan sebagai sebuah komitmen perusahaan untuk berkontribusi dalam perwujudan pembangunan ekonomi berkelanjutan. Organisation for Economic Cooperation and Development (OECD) menerapkan suatu konsep yakni People, Planet, Prosperity, Partnership dan Peace sesuai dengan sustainable development goals (SDG). Dalam konsep ini dikatakan bahwa guna memenuhi SDG yang memiliki multi dimensi, maka perlu sinergi berkaitan dengan pengembangan (OECD.org, 2015).

Dalam Undang-Undang nomor 40 tahun 2007 (UUPT) pasal 74 dikatakan bahwa ada 2 kriteria perusahaan yang harus menjalankan CSR. Pertama, perseroan yang menjalankan usahanya di bidang sumber daya alam. Kedua, perseroan yang menjalankan kegiatan usahanya berkaitan dengan sumber daya alam. Pada kriteria kedua mengacu kepada perseroan yang tidak mengelola dan tidak memanfaatkan sumber daya alam, tetapi dalam kegiatan usahanya memiliki dampak pada sumber daya 
alam. Contoh kegiatan CSR yang berhubungan dengan lingkungan salah satunya adalah yang dilakukan oleh PT. Djarum dan dipublikasikan lewat website-nya djarumfoundation.org. Seperti yang kita ketahui bahwa PT Djarum merupakan produsen rokok yang memanfaatkan sumber daya alam untuk perkebunannya. Selain itu, sampah yang dihasilkan oleh rokok berupa puntung rokok merupakan salah satu sampah yang kerap kali menjadi masalah lingkungan. Dalam kegiatan bersih pantai yang dilakukan oleh oceanconservancy.org pada tahun 2017 mengemukakan bahwa sampah puntung rokok merupakan sampah terbanyak yang ditemukan sepanjang garis pantai. Atas kesadaran kerusakan lingkungan yang tercipta akibat produknya, PT. Djarum berkomitmen untuk melakukan pemeliharaan lingkungan. Salah satunya adalah dengan melakukan penanaman 41.758 pohon trembesi sepanjang Merak hingga Banyuwangi dalam periode 2010-2015 (djarumfoundation.org, 2012).

Berkembangnya kesadaran atas pelestarian lingkungan mendorong opini minat masyarakat terhadap perusahaan yang berkontribusi dalam pelestarian lingkungan. Hal ini juga direspon oleh perusahaan guna meningkatkan pandangan positif publik terhadap perusahaan tersebut. Pengungkapan laporan CSR dirasa penting guna menciptakan citra yang baik di masyarakat. Mantan menteri lingkungan hidup menjelaskan bahwa "Pengungkapan CSR bermanfaat guna menghindari investasi dari resiko lingkungan. Maka dari itu perusahaan yang telah melakukan laporan berkelanjutan harus diapresiasi. Meningkatnya kesadaran perusahaan untuk melakukan pengungkapan CSR secara sederhana dapat dilihat dari meningkatnya peserta Indonesian Sustainability Reporting Award setiap tahunnya (kompas.com, 2015).

Hasil beberapa penelitian yang dilakukan menunjukkan adanya dampak positif dari pengungkapan CSR terhadap perusahaan, yakni pengambilan keputusan ekonomi investor saat ini tidak hanya melihat kinerja keuangan namun mempertimbangkan juga berbagai kegiatan CSR yang dilakukan oleh entitas. Oleh karena itu, perusahaan dapat memanfaatkan berbagai kegiatan CSR sebagai salah satu keunggulan kompetitif perusahaan. Yang mana pengungkapan CSR yang dilakukan perusahaan diharapkan mampu memberikan signal positif dan dapat meningkatkan nilai perusahaan di mata investor. 
Berdasarkan teori pasar efisien, reaksi investor atas suatu informasi perusahaan dapat terlihat dari nilai harga pasar perusahaan tersebut (Jogiyanto, 2009). Apabila informasi CSR dipertimbangkan investor dalam pengambilan keputusan yang diikuti dengan kenaikan pembelian saham perusahaan sehingga terjadi kenaikan harga saham yang melebihi return yang diekspektasikan oleh investor dan pada akhirnya informasi CSR merupakan informasi yang memberikan nilai tambah bagi investor dan menyebabkan abnormal return.

Di Indonesia, penelitian Nurdin dan Cahyandito (2006) menunjukan bahwa pengungkapan kegiatan sosial dan lingkungan dalam laporan tahunan berpengaruh signifikan terhadap reaksi investor yang diukur dengan abnormal return dan volume perdagangan saham. Hal ini konsisten dengan Sayekti dan Ludovicus (2007) yang menyimpulkan bahwa pelaksanaan CSR memiliki dampak positif dan signifikan terhadap reaksi pasar. Namun demikian, pada penelitian-penelitian lain menunjukan hasil yang tidak konsisten. Di antaranya adalah penelitian Lorraine (2004), Dahlia dan Veronica (2008), di mana pengungkapan CSR tidak berpengaruh terhadap reaksi pasar.

Penelitian ini berbeda dengan penelitianpenelitian sebelumnya. Penelitian ini berfokus pada perusahaan-perusahaan yang berhubungan dengan sumber daya alam mengingat Undang-Undang No. 40 Tahun 2007 tentang Perseroan Terbatas (pasal 74 ayat 1a) yang mewajibkan perusahaan yang kegiatan usahanya di bidang dan/atau berkaitan dengan sumber daya alam untuk melakukan CSR. Selain itu, menurut Hackston dan Milne (1996) dalam Suwardi et al. (2010) mengatakan bahwa perusahaan yang mempunyai tingkat sensitivitas yang tinggi terhadap lingkungan (rawan lingkungan) termasuk dalam tipe industri high profile. Perusahaan ini pada umumnya merupakan perusahaan yang memperoleh sorotan masyarakat karena aktivitas operasinya memiliki potensi untuk bersinggungan dengan kepentingan luas. Pemilihan industri pertambangan batu bara sebagai subjek penelitian didasarkan oleh kontribusi kerusakan lingkungan yang disebabkan oleh industri tersebut cukup tinggi. Menurut laporan yang dikeluarkan oleh Greenpeace Indonesia pada 2016, menungkapkan bahwa industri pertambangan 
khususnya batubara menerapkan produksi yang eksesif, di mana produksi batubara jauh di atas kebutuhan konsumsinya yang berimbas pada kerusakan lingkungan yang cukup parah (Greenpeace, 2016).

KAJIAN TEORI DAN PENGEMBANGAN HIPOTESIS

Signaling Theory

Signaling Theory atau teori sinyal adalah sebuah teori yang menggambarkan hubungan antara penyedia informasi dengan pemakai informasi, dalam hal ini bisa dikatakan sebagai agent dan pricipal atau management dengan investor (Cahyani, 2009). Dalam hubungan asimetris tersebut suatu informasi yang dimiliki oleh emiten akan dijadikan suatu sinyal guna menarik pihak eksternal. Menurut Rokhlinasari (2016) suatu emiten akan menyebarkan informasi yang dianggap sebagai suatu sinyal dengan melakukan pengungkapan informasi. Pengungkapan informasi dalam suatu emiten dapat berupa laporan keungan, hasil pengungkapan laporan keungan tersebut akan memberikan sinyal baik (good news) jika perusahaan mempunyai prospek yang baik atau sinyal buruk (bad news) jika kinerja perusahaan sedang buruk. Dari hasil sinyal yang diterima pihak eksternal tersebut nantinya akan mempengaruhi perspektif eksternal dan menyebabkan naik turunnya nilai atau harga sekuritas dari suatu emiten (Rokhlinasari, 2016).

Rokhinasari (2016) menjelaskan bahwa kegiatan CSR merupakan suatu sinyal yang kuat guna merepresentasikan management yang berkualitas baik. Hal senada juga dikemukakan oleh Gray et al. (1995) dalam Rokhinasari (2016) yang mengungkapkan bahwa perusahaan dengan kualitas pengelolaan yang tinggi akan melakukan pengungkapan lingkungan dan akuntansi sosial. Sedangkan perusahaan dengan kualitas pengelolaan rendah cenderung memilih untuk membatasi pengungkapan informasi kepada pihak eksternal. Dengan pengungkapan informasi yang baik terkait kualitas pelaporan keuangan dapat memberikan sinyal positif bahwa emiten telah mampu mengontrol risiko sosial dan lingkungan yang dapat mempengaruhi perusahaan di masa depan.

\section{Corporate Social Responsibility}

World Business Council for Sustainable Development menjelaskan CSR merupakan suatu komitmen berkelanjutan oleh dunia usaha untuk bertindak secara etis dan memberikan 
kontribusi kepada pengembangan ekonomi dari komunitas setempat ataupun masyarakat secara luas, bersamaan dengan peningkatan taraf hidup pekerjanya beserta seluruh keluarganya. Sedangkan, menurut ISO 26000, CSR adalah Tanggung jawab sebuah organisasi terhadap dampak-dampak dari keputusan-keputusan dan kegiatan-kegiatannya pada masyarakat dan lingkungan yang diwujudkan dalam bentuk perilaku transparan dan etis yang sejalan dengan pembangunan berkelanjutan dan kesejahteraan masyarakat, mempertimbangkan harapan pemangku kepentingan, sejalan dengan hukum yang ditetapkan dan norma-norma perilaku internasional, serta terintegrasi dengan organisasi secara menyeluruh. Perusahaan selain berorientasi terhadap laba perlu juga bertanggungjawab terhadap masalah sosial yang ditimbulkan oleh aktivitas operasional yang dilakukan perusahaan dengan manajemen lingkungan sehingga tidak hanya terbatas pada orientasi kinerja keuangan perusahaan. Banyak manfaat yang dapat diperoleh atas aktivitas CSR antara lain: meningkatkan penjualan dan market share, memperkuat brand positioning, meningkatkan citra perusahaan, menurunkan biaya operasi, dan meningkatkan daya tarik perusahaan di mata para investor dan analisis keuangan. Dengan menjalankan tanggung jawab sosial, perusahaan diharapkan tidak hanya mengejar keuntungan jangka pendek, namun juga turut memberikan kontribusi bagi peningkatan kesejahteraan dan kualitas hidup masyarakat serta lingkungan sekitar dalam jangka panjang. Dengan melaksanakan CSR secara konsisten dalam jangka panjang akan menumbuhkan rasa keberterimaan masyarakat terhadap kehadiran perusahaan.

Pengungkapan CSR merupakan bagian dari akuntansi pertanggung jawaban sosial yang mengkomunikasikan informasi sosial kepada stakeholder. Menurut Guthrie dan Parker (1990) sebagaimana dikutip oleh Sayekti dan Ludovicus (2007), pengungkapan informasi CSR dalam laporan tahunan merupakan salah satu cara perusahaan untuk membangun, mempertahankan, dan melegitimasi kontribusi perusahaan dari sisi ekonomis dan politis. Selain itu juga, akuntansi pertanggungjawaban sosial dapat memberikan informasi mengenai sejauh mana organisasi atau perusahaan memberikan kontribusi positif maupun negatif terhadap kualitas hidup manusia dan lingkungannya. Tanggungjawab sosial perusahaan bersifat wajib (mandatory) bagi kriteria perusahaan tertentu seperti yang 
disebutkan dalam UU No. 40 Tahun 2007

tentang Perseroan Terbatas pasal 74

menyatakan bahwa: Perseroan yang

menjalankan usahanya di bidang dan atau

berkaitan dengan sumber daya alam wajib

melaksanakan tanggungjawab sosial dan

lingkungan. Tanggungjawab sosial dan

lingkungan tersebut merupakan kewajiban

perseroan yang dianggarkan dan

diperhitungkan sebagai biaya perseroan yang

pelaksanaanya dilakukan dengan

memperhatikan kepatuhan dan kewajaran. Jika

Perseroan yang tidak melaksanakan kewajiban tanggung jawab sosial akan dikenai sanksi sesuai dengan ketentuan peraturan perundangundangan. Selain perusahaan wajib melakukan kegiatan CSR, UU No. 40 Tahun 2007 pasal 66 ayat (2) tentang Perseroan Terbatas juga mewajibkan perusahaan untuk mengungkapkan aktivitas tanggung jawab sosialnya dalam laporan tahunan. Namun demikian, item-item CSR yang diungkapkan perusahaan merupakan informasi yang masih bersifat sukarela (voluntary).

Konsep pelaporan CSR yang digagas oleh Global Reporting Initiative (GRI) adalah konsep sustainability report yang muncul sebagai akibat adanya konsep sustainability development. Dalam sustainability report digunakan metode triple bottom line, yang tidak hanya melaporan sesuatu yang diukur dari sudut pandang ekonomi saja, melainkan dari sudut pandang ekonomi, sosial dan lingkungan. Gagasan ini merupakan akibat dari adanya 3 dampak operasi perusahaan yaitu ekonomi, sosial dan lingkungan. GRI Guidelines menyebutkan bahwa, perusahaan harus menjelaskan dampak aktivitas perusahaan terhadap ekonomi, lingkungan dan sosial pada bagian standard disclosures. Yang kemudian ketiga dimensi tersebut diperluas menjadi 6 dimensi, yaitu: ekonomi, lingkungan, praktek tenaga kerja, hak asasi manusia, masyarakat, dan tanggungjawab produk.

Berbagai alasan perusahaan dalam melakukan pengungkapan informasi CSR telah banyak diteliti dalam penelitian sebelumnya (Basamalah et al, 2005; dalam Sayekti dan Ludovicus, 2007), di antaranya adalah karena untuk menaati peraturan yang ada, untuk memperoleh keunggulan kompetitif melalui penerapan CSR, untuk memenuhi ketentuan kontrak pinjaman dan memenuhi ekspetasi masyarakat, untuk melegitimasi tindakan perusahaan, serta untuk menarik investor. 


\section{Abnormal Return}

Abnormal return adalah salah satu indikator yang digunakan untuk melihat keadaan pasar yang sedang terjadi. Pasar modal akan bereaksi ketika informasi yang disajikan perusahaan mempunyai nilai guna dalam memengaruhi keputusan. Suatu informasi baik penyajian maupun pengungkapan akan ditanggapi oleh investor dengan beragam reaksi. Maka dari itu perlu dilakukannya perhitungan atas kemungkinan keuntungan menyimpang dari yang diharapkan atau sering disebut abnormal return. Abnormal return adalah selisih antara tingkat keuntungan yang sebenarnya dengan tingkat keuntungan yang diharapkan. Pasar dikatakan efisien jika tidak satupun pelaku pasar yang menikmati abnormal return dalam jangka waktu yang cukup lama. Hal ini disebabkan karena abnormal return merupakan return yang tidak dapat diprediksikan sehingga jika pelaku pasar masih banyak yang menikmati abnormal return, itu berarti informasi yang tersedia belum mencerminkan harga sekuritas yang diperdagangkan sehingga akan mempengaruhi efisiensi pasar.

Abnormal return akan positif jika return yang didapatkan lebih besar dari return yang diharapkan, sedangkan abnormal return akan negatif jika return yang didapatkan lebih kecil daripada return yang diharapkan. Suatu perusahaan dengan presentase Expected Return yang sama dapat memiliki kemungkingnan Actual Return yang berbeda (Husnan, 2005). Jogiyanto (2017) mendefinisikan bahwa abnormal return adalah selisih antara Actual Return dengan return yang diestimasikan. Abnormal return akan positif jika return yang diperoleh oleh perusahan lebih besar dari return yang diestimasikan. Sebaliknya jika return yang didapatkan lebih kecil daripada return yang diekspektasikan maka hal tersebut dapat dikatakan sebagai Abnormal Return negatif.

\section{Pengembangan Hipotesis}

Hubungan Pengungkapan CSR dalam Laporan Tahunan dan Abnormal Return

Menurut ISO 26000, CSR merupakan sebuah tanggung jawab organisasi atas dampak keputusan yang diambil. Maka dapat dikatakan bahwa CSR merupakan bentuk tanggung jawab perusahaan bukan hanya terhadap masyarakat namun juga pada stakeholder. Jika dikaitkan dengan Signaling Theory dikatakan bahwa CSR merupakan suatu sinyal yang kuat guna merepresentasikan management berkualitas baik (Rokhinasari, 2016). Sehingga akan 
penting bagi perusahaan memancarkan signal positif kepada pihak eksternal, signal positif ini diharapkan dapat menghasilkan respon positif dari pasar (Vivi, 2013). Adapun reaksi yang beragam dari investor terhadap pengungkapan CSR diukur dengan Abnormal Return atas informasi yang memberikan keyakinan pada prospek perusahaan dimasa depan.

Berdasarkan hasil penelitian terdahulu dan teori yang telah dijabarkan di atas, maka hipotesis yang diajukan dalam penelitian ini adalah sebagai berikut:

H0: Pengungkapan informasi CSR tidak berpengaruh positif terhadap Abnormal Return. H1: Pengungkapan informasi CSR berpengaruh positif terhadap Abnormal Return.

\section{Kerangka Penelitian}

Sesuai dengan kajian literatur dan hasilhasil penelitian terdahulu yang berkaitan dengan CSR dan Abnormal Return dapat disimpulkan kerangka teoris sebagaimana terdapat pada gambar 1 .

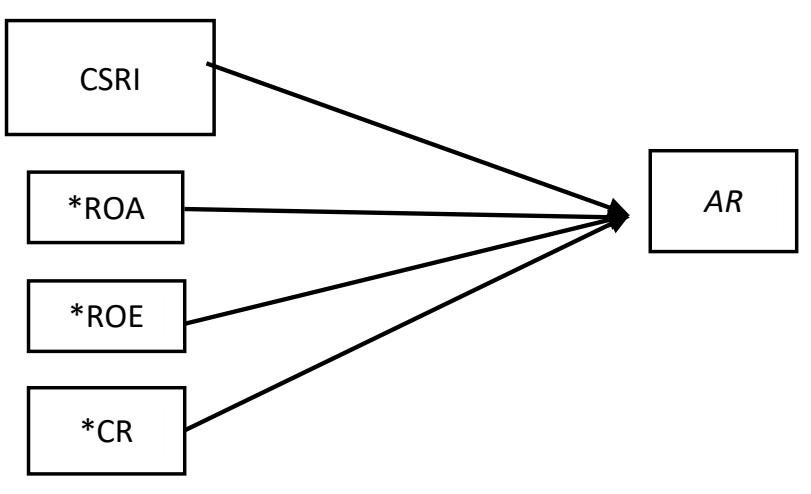

*ROE, ROA dan Current Ratio sebagai variabel kontrol

\section{Gambar 1. Kerangka Penelitian}

\section{METODE RISET}

\section{Desain Penelitian}

Jenis penelitian yang dilakukan dalam penelitian ini adalah penelitian kuantitatif. Sehingga penelitian ini akan melihat ada tidaknya hubungan sebab akibat antara variabel independen dengan dependen. Data yang digunakan dalam penelitian ini berjenis time series pada laporan keuangan perusahaan, karena data yang diolah dalam penelitian ini berdasarkan suatu waktu yang berkelanjutan.

\section{Populasi, Sampel, dan Teknik Analisis Data}

Dalam penelitian ini yang dijadikan populasi adalah seluruh perusahaan pertambangan batu bara yang terdaftar dalam Bursa Efek Indonesia yakni terdapat 11 perusahaan selama periode 2013-2017. Pemilihan tahun 2013-2017 didasarkan pada saran peneliti terdahulu Vivi (2013) untuk 
menggunakan tahun penelitian lebih panjang. Dengan masa tahun terbit laporan keuangan yang lebih panjang, yakni 5 tahun, diharapkan dapat berguna untuk menjawab keterbatasan dari penelitian sebelumnya. Dengan harapan bahwa jumlah sampel yang lebih besar dengan periode yang lebih panjang akan memberikan kemungkinan yang lebih besar untuk memperoleh hasil yang mendekati kondisi sebenarnya. Sampel yang diambil dalam penelitian ini dilakukan dengan purposive sampling. Adapun kriteria yang digunakan untuk mendapatkan sampel adalah: (1) Perusahaan pertambangan yang terdaftar di BEI selama tahun 2013-2017 secara berturut-turut; (2) Perusahaan Pertambangan yang menerbitkan laporan tahunan selama tahun 2013-2017 secara berturut-turut; dan (3) Perusahaan pertambangan mengungkapkan Corporate Social Responsibility dalam laporan tahunan selama 2013-2017.

\section{Jenis dan Sumber Data}

Dalam penelitian ini, data yang digunakan adalah data sekunder. Data sekunder sendiri merupakan data yang diperoleh peneliti dari sumber yang sudah ada. Dalam penelitian ini data sekunder yang dipakai berupa laporan tahunan yang dipublikasikan melalui Bursa Efek Indonesia (www.idx.co.id) dalam periode penelitian 2013-2017.

\section{Metode Pengumpulan Data}

Metode pengumpulan data dalam penelitian ini adalah menggunakan metode studi pustaka. Dalam metode studi pustaka, data diperoleh dengan mencari informasi lewat majalah, koran, buku, dan literatur dengan tujuan untuk membentuk suatu landasan teori. Literatur dalam hal ini adalah penelitian yang pernah dilakukan oleh peneliti sebelumnya dijadikan acuan dalam melakukan penelitian ini.

\section{Definisi Operasional dan Pengukuran} Data Variabel

Tujuan dari penelitian ini adalah untuk menganalisis pengaruh antara variabel independen dengan variabel dependen sebagaimana dijelaskan di bawah ini.

\section{Variabel Dependen}

Variabel Depeden dalam penelitian ini adalah abnormal return yang diukur dengan commulative abnormal return (CAR) dimana CAR dapat dihitung dengan rumus sebagai bertikut: 


\section{$\mathrm{CARi}, \mathrm{t}=\Sigma \mathrm{AR} \mathbf{i}, \mathrm{t}$}

Keterangan:

CARi,t = cummulative abnormal return saham perusahaan i pada periode $t$, yang diakumulasi dari abnormal return saham perusahaan i

$\mathrm{ARi}, \mathrm{t}=$ abnormal return sekuritas perusahaan i pada periode ke-t .

Periode jendela pada penelitian ini adalah 10 hari sebelum dan sesudah publikasi laporan tahunan.

Rumus untuk menghitung Abnormal Return, Actual Return dan Expected Return terdapat dalam gambar 2, 3 dan 4 .

Variabel Independen

Variabel Indepeden dalam penelitian ini adalah Corporate Social Responsibility. Dalam penelitian ini CSR akan dihitung menggunakan CSR Index di mana hal ini akan berkaitan dengan pemenuhan 78 item pengungkapan yang ditetapkan pada Sustainability Reporting Guidelines (SRG) yang dikeluarkan oleh Global Reporting Initiative (GRI) (globalreporting.org, 2016). Penilaian dilakukan dengan memberikan skor angka 1 pada item di SRG yang diungkapkan. Atau memberikan skor 0 untuk informasi yang tidak diungkapkan.
Menghitung Abnormal Return

ARit $=$ Rit - ER

Keterangan:

ARit = abnormal return sekuritas perusahaan i pada periode ke-t

Rit = actual return yang terjadi pada perusahaan i pada periode ke-t

$\mathrm{ER}=$ expected return

Gambar 2. Perhitungan Abnormal Return

Menghitung Actual Return

Keterangan:

Rit $=\frac{\text { Pit }- \text { Pit }-1}{\text { Pit }-1}$

Rit $=$ Return sesungguhnya yang terjadi

pada perusahaan i pada periode ke-t

Pi.t $=$ Harga saham $\mathrm{i}$ pada periode $\mathrm{t}$

Pi.t-1 = Harga saham i pada periode $\mathrm{t}-1$

Gambar 3. Perhitungan Actual Return

$E R=\frac{I H S G t-I H S G t-1}{I H S G t-1}$

Keterangan :

$\mathbf{E R}=$ Expected Return

IHSGt $=$ Indeks Harga Saham Gabungan pada Periode ke $\mathrm{t}$

IHSGt-1 = Indeks Harga Saham Gabungan pada Periode ke

Gambar 4. Perhitungan Expected Return

Teknik Analisis Data

Dalam penelitian ini, data dianalisis menggunakan analisis regresi linear berganda. Pada hasil analisa regresi ini akan dilihat hubungan sebab akibat antara variabel penyebab atau yang disebut $\mathrm{X}$, dengan variabel akibatnya atau yang disebut Y.

\section{Analisis Deskriptif}

Analisis deskriptif adalah statistik yang digunakan sebagai bahan analisis data dengan 
cara deskriftif atas data yang terkumpul (Vivi, 2013). Pada penelitian ini, penyajian data menggunakan tabel dan analisis data berdasarkan nilai maksimum, minumim, mean, dan Standar Deviasi.

Uji Asumsi Klasik

Uji asumsi klasik yang dilakukan dalam penelitian ini terdiri dari:

A. Uji Normalitas

Uji Normalitas adalah suatu pengujian untuk melihat tingkat normalitas atas penyebaran data. Jika hasil pengujian menunjukkan signfikansi di atas 0,05 , maka dapat dikatakan terdistribusi normal (Ghozali dan Imam, 2013)

\section{B. Uji Heteroskedastisitas}

Uji heteroskedastisitas adalah suatu uji yang dilakukan dengan melihat pola yang tidak sama ditunjukkan dengan nilai yang tidak sama antar satu varians, hal ini dilakukan dengan melihat pola grafik scatterplot. Jika hasil dari grafik scatterplot menunjukkan tidak ada pola yang jelas serta titik menyebar di atas dan di bawah angka 0 pada sumbu Y maka tidak terjadi heterokedastisitas (Vivi,
2013). Atau jika hasil heterokedastisitas memiliki signifikansi di atas 0,05.

C. Uji Autokoreksi

Uji ini bertujuan untuk melihat apakah terjadi korelasi antara suatu periode dengan periode sebelumnya (Vivi, 2013).

D. Koefisien Determinasi

Uji ini bertujuan untuk melihat sejauh mana kemampuan varibel independen untuk menjelaskan variabel dependen dalam regresi linear.

\section{Pengujian Hipotesis}

Hipotesis penelitian akan diuji dengan persamaan regresi sebagai berikut:

$$
C A R=\beta_{0}+\beta_{1} C S R I+\beta_{2} R O A+\beta_{2} R O E
$$

$$
+\beta_{2} C R+\varepsilon
$$

Keterangan :

CAR : Commulative Abnormal Return

$\boldsymbol{\beta}_{\mathbf{0}} \quad$ : Konstanta persamaan regresi

$\boldsymbol{\beta}_{1}$ CSRI: Koefisien regresi pada Corporate Social Responsibility Index

$\boldsymbol{\beta}_{2} \boldsymbol{R O A}$ : Koefisien regresi return non assets perusahaan

$\boldsymbol{\beta}_{3} \boldsymbol{R O E}$ : Koefisien regresi return non equity perusahaan 
$\boldsymbol{\beta}_{\mathbf{2}} \boldsymbol{C R}$ : Koefisien regresi current assets perusahaan

$\boldsymbol{\varepsilon} \quad$ : Error

\section{HASIL PENELITIAN DAN}

PEMBAHASAN

Dalam penelitian ini, data yang dipakai berupa laporan tahunan yang dipublikasikan melalui Bursa Efek Indonesia (www.idx.co.id) dalam periode penelitian 2013-2017. Sedangkan yang dijadikan populasi dalam penelitian ini adalah industri pertambangan batu bara sebanyak 22 perusahaan. Dari 22 perusahaan tersebut ditarik sampel dengan menggunakan purposive sampling berdasarkan 4 kriteria yang menghasilkan 11 perusahan pertambangan batu bara untuk diteliti. Data yang dianalisis dalam penelitian ini terdiri dari dua variabel yakni Corporate Social Responsibility sebagai varibal independen, Abnormal Return sebagai variabel dependen dan ROA, ROE, Current Ratio sebagai variabel kontrol. Berikut ini akan dijelaskan deskripsi data atas variabel-variabel tersebut dengan menggunakan statistik deskriptif.
Statistik Deskriptif

Tabel 1. Hasil Statistik Deskriptif

\begin{tabular}{|l|c|c|c|}
\hline \multicolumn{1}{|c|}{$\begin{array}{c}\text { Statistik } \\
\text { Deskriptif }\end{array}$} & Min & Maks & Mean \\
\hline CSRI & 0,15 & 0,31 & 0,208 \\
\hline $\begin{array}{l}\text { Abnormal } \\
\text { Return }\end{array}$ & $-0,013$ & 0,014 & $-0,0008$ \\
\hline ROA & $-0,644$ & 0,781 & 0,127 \\
\hline ROE & $-0,739$ & 3,65 & 6,62 \\
\hline $\begin{array}{l}\text { Current } \\
\text { Ratio }\end{array}$ & 0,10 & 6,92 & 2,183 \\
\hline
\end{tabular}

Pada tabel 1 disajikan statistik deskriptif atas variabel-variabel yang ada dalam penelitian ini yakni Corporate Social Responsibility yang direpresentasikan dalam CSRI, dan Abnormal Return.

Pada Tabel 1 tertera rata-rata Cummulative Abnormal Return pada 55 data observasi yang digunakan adalah sebesar 0,00089. Hal ini menunjukan bahwa selama periode 2013-2017, perusahan pertambangan batu bara rata-rata memiliki abnormal return yang negatif. Artinya tingkat actual return kebanyakan perusahaan pertambangan batu bara lebih kecil dibandingkan dengan expected returnnya atau dalam penelitian ini IHSG. Secara singkat dapat dikatakan return industri pertambangan batu bara di bawah dari return rata-rata industri.

Corporate Social Responsibility Indeks pada 55 data observasi yang digunakan 
mempunyai rata-rata sebesar 0,208 atau 20,86\% dan mempunyai tingkat penyimpangan atau standar deviasi sebesar 3,25\%. Artinya rata-rata perusahaan pertambangan melakukan pengungkapan Corporate Social Responsibiliity pada laporan tahunannya hanya sebesar $20,86 \%$ dari 78 item kriteria yang ditetapkan atau panduan dalam pengungkapan CSR.

\section{Uji Asumsi Klasik}

\section{Uji Normalitas}

Pengambilan Keputusan dalam penelitian ini berkaitan normalitas dapat dibuktikan dari pengujian One-Sample Kolmogorov-Smirnov Test. Dengan tingkat signifikansi 0,05 apabila $\mathrm{P}>0,05$ maka dapat disimpulkan bahwa data terdistribusi normal. Dari hasil pengujian yang dapat dilihat pada table 2 bahwa nilai Probabilitas sebesar 0,82> 0,05 maka dapat dikatakan data terdistribusi secara normal.

\section{Uji Heterokedastisitas}

Dari hasil pengujian Pengujian dengan Uji Glejser ditemukan hasil bahwa nilai signifikansi untuk semua variabel di atas 0,005. Hal ini menunjukan hasil pengujian atas semua variabel tidak memiliki gejala heterokedastisitas.
Tabel 2. Hasil Uji Normalitas

\begin{tabular}{|l|l|r|}
\hline \multicolumn{2}{|c|}{} & \multicolumn{1}{|c|}{$\begin{array}{c}\text { Unstandardized } \\
\text { Residual }\end{array}$} \\
\hline $\mathrm{N}$ & & 55 \\
\hline $\begin{array}{l}\text { Normal } \\
\text { Parameters }\end{array}$ & Means & OE-7 \\
\cline { 2 - 3 } & $\begin{array}{l}\text { Std. } \\
\text { Deviation }\end{array}$ & .00630977 \\
\hline $\begin{array}{l}\text { Most Extreme } \\
\text { Differences }\end{array}$ & Absolute & .085 \\
\cline { 2 - 3 } & Positive & .084 \\
\cline { 2 - 3 } & Negative & -.085 \\
\hline $\begin{array}{l}\text { Kolmogorov- } \\
\text { Smirnov Z }\end{array}$ & & .631 \\
\hline $\begin{array}{l}\text { Asymp. Sig. } \\
(2-t a i l e d)\end{array}$ & & .820 \\
\hline
\end{tabular}

a. Test distribution is Normal

b. Calculated from data

Tabel 3. Hasil Pengujian Uji Glejser

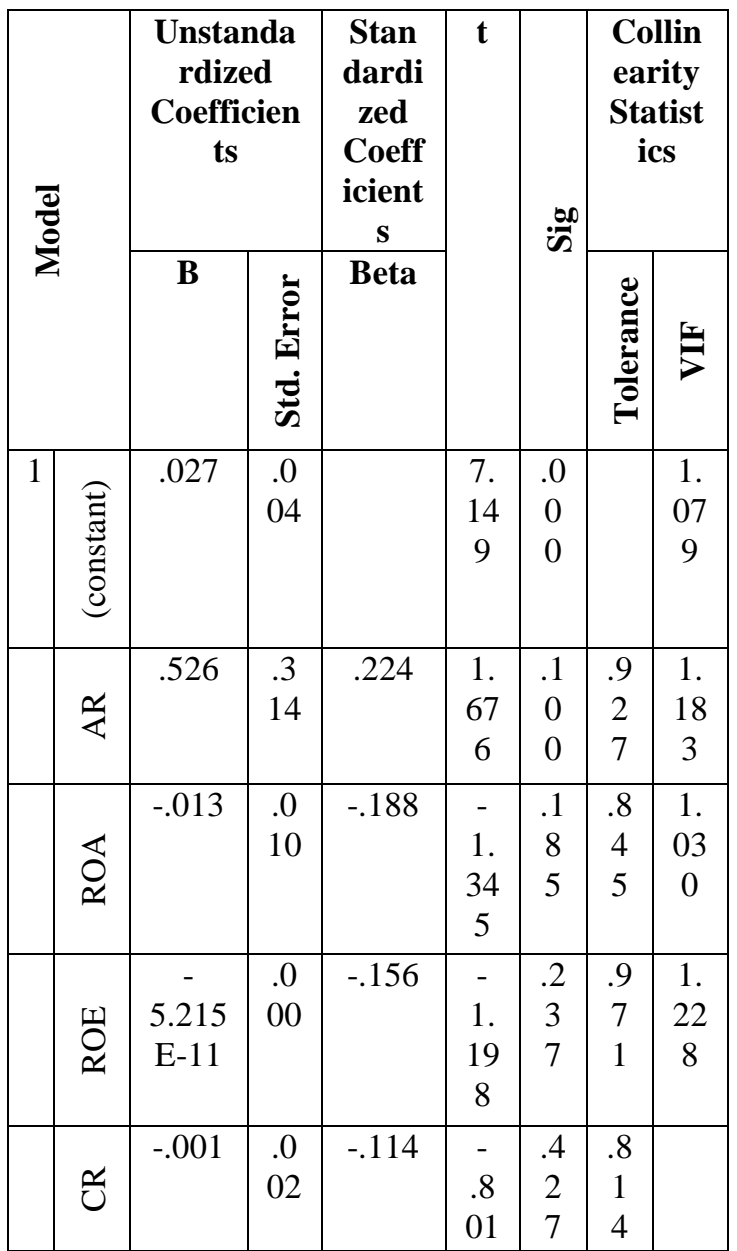


Tabel 4. Hasil Run Test

\begin{tabular}{|l|r|}
\hline & $\begin{array}{l}\text { Unstandardized } \\
\text { Residual }\end{array}$ \\
\hline Test Value & \\
\hline Cases $<$ Test Value & -.00001 \\
\hline Cases >= Test Value & 27 \\
\hline Total Cases & 28 \\
\hline Number of Runs & 55 \\
\hline Z Sig. (2- & 23 \\
\hline $\begin{array}{l}\text { Asymp. } \\
\text { tailed) }\end{array}$ & -1.495 \\
\hline
\end{tabular}

a. Median

\section{Uji Autokoreksi}

Setelah dilakukannya run test yang ditunjukkan pada tabel 4 ditemukan hasil bahwa Asymp. Sig. (2-tailed) di atas 0,05 yakni 0,135 maka dapat disimpulkan bahwa tidak ada gejala autokoreksi.

\section{Koefisien Determinasi}

Uji Koefisiensi Determinasi bertujuan untuk melihat sejauh mana kemampuan varibel independen untuk menjelaskan variabel dependen dalam regresi linear. Dalam penelitian ini diuji dengan tabel model summary sebagaimana terdapat pada tabel 5 .

Dari tabel tersebut dapat ditemukan bahwa varian variabel Corporate Social Responsibility dapat menjelaskan varian Abnormal Return sebesar 21,5\% sedangkan sisanya sebesar $78,5 \%$ varian variabel Abnormal Return dijelaskan oleh varian variabel lain yang tidak diteliti.
Tabel 5. Hasil Koefisien Determinasi (Model Summary $^{\mathrm{b}}$ )

\begin{tabular}{|c|c|c|c|c|c|}
\hline$\frac{\bar{d}}{\delta}$ & $\mathbf{R}$ & 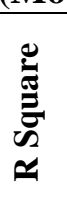 & 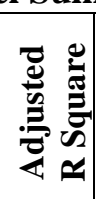 & 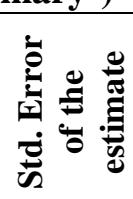 & $\begin{array}{l}\text { Durbin- } \\
\text { Watson }\end{array}$ \\
\hline 1 & $.461^{\mathrm{a}}$ & .213 & .150 & $\begin{array}{l}.00644 \\
10\end{array}$ & 1.925 \\
\hline
\end{tabular}

\section{Pengujian Hipotesis}

Uji regresi berganda adalah analisis nilai pengaruh dua variabel bebas atau lebih terhadap satu variabel terikat. Tabel 6 menyajikan hasil pengujian SPSS model penelitian.

Berdasarkan hasil uji statistik F, didapatkan nilai $\mathrm{F}$ hitung sebesar 4.987 dengan nilai signifikansi sebesar 0,002 . Hal ini menunjukkan bahwa pengungkapan informasi CSR oleh perusahaan tambang mempengaruhi langsung abnormal return perusahaan tersebut. Hasil regresi pada tabel 6, diperoleh model persamaan regresi sebagai berikut:

$$
\begin{gathered}
\text { CSRI }=-0,018+0,087 \text { CSRI }-0,002 \\
\text { ROA }-1,042 \text { ROE }-0,001 \text { CR }
\end{gathered}
$$


Tabel 6. Hasil Regresi CSRI dan Abnormal Return

\begin{tabular}{|l|c|c|c|}
\hline \multicolumn{1}{|c|}{$\begin{array}{c}\text { VARIABEL } \\
\text { INDEPENDEN }\end{array}$} & B & t & Sig. \\
\hline Constant & $-0,018$ & 31,386 & 0,000 \\
\hline $\begin{array}{l}\text { Corporate Social } \\
\text { Responsibility } \\
\text { Index (CSRI) }\end{array}$ & 0,087 & 2,974 & 0,005 \\
\hline $\begin{array}{l}\text { Return on Assets } \\
\text { (ROA) }\end{array}$ & $-0,002$ & 0,571 & 0,570 \\
\hline $\begin{array}{l}\text { Return on Equity } \\
\text { (ROE) }\end{array}$ & $-1,042$ & $-0,058$ & 0,954 \\
\hline $\begin{array}{l}\text { Current Ratio } \\
\text { (CR) }\end{array}$ & $-0,001$ & $-1,334$ & 0,188 \\
\hline \multicolumn{1}{|c|}{ Variabel } & Cumulative Abnormal \\
Return \\
\hline Dependen: $^{2}$
\end{tabular}

\section{Pembahasan}

Hasil dari beberapa penelitian yang dilakukan oleh peneliti terdahulu mengemukakan bahwa pengungkapan CSR berpengaruh signifikan terhadap abnormal return. Hal ini seperti yang dikemukakan oleh Cheng (2011) dan Vivi (2013) dalam penelitiannya. Hasil demikian terjadi karena adanya sinyal positif yang dipancarkan lewat pengungkapan CSR yang dilakukan perusahaan dalam laporan tahunannya. Pengungkapan CSR mempunyai kandungan informasi yang membuat investor dapat bereaksi dan beropini atas prospek perusahaan di masa depan. Didasarkan dari opini dan reaksi tersebut pengungkapan CSR dapat diartikan sebagai guarantee atas keberlangsungan perusahaan (Cheng dan Christiawan, 2011).

Pada penelitian yang diaplikasikan di industri pertambangan batu bara dapat kemukakan bahwa hasil yang ditemukan mendukung apa yang telah dikemukakan oleh peneliti-peneliti sebelumnya di industri yang berbeda. Pada pengujian ini, hasil penelitian menunjukkan Pengungkapan CSR memiliki pengaruh dengan nilai $\mathrm{t}$ hitung 2,974 dan siginikansi 0,005 atau lebih kecil dari 0,05. Penelitian ini juga mengungkapkan bahwa dalam periode jendela 10 hari sebelum dan 10 hari sesudah tanggal publikasi laporan tahunan, pengungkapan CSR berpengaruh terhadap abnormal return perusahaan. Hal ini menunjukkan bahwa investor di pasar saham Indonesia menggunakan informasi pengungkapan CSR dalam melakukan keputusan investasi. Hal ini menunjukan bahwa pasar modal Indonesia sedang mengarah atau mengikuti trend global, di mana pengungkapan CSR menjadi hal sensitif dalam pengambilan keputusan investasi bagi investor untuk berinvestasi (Cheng dan Christiawan, 2011). 


\section{KESIMPULAN DAN SARAN}

Penelitian ini bertujuan untuk mengetahui ada tidaknya pengaruh dari pengungkapan Corporate Social Responsibility terhadap Abnormal return dari perusahaan di industri pertambangan batu bara. Dalam penelitian ini terjawab bahwa ternyata pengungkapan CSR memiliki pengaruh terhadap Abnormal Return perusahaan. Hal ini menunjukan bahwa Investor pada pasar modal Indonesia khususnya dalam kasus ini adalah industri pertambangan cukup reaktif dengan isu-isu CSR yang dilakukan perusahaan.

\section{Keterbatasan Penelitian}

Dalam melakukan Penelitian ini, peneliti hanya menggunakan 11 perusahaan yang dapat diteliti. Hal ini disebabkan oleh perusahaan dalam industri pertambangan batu bara masih memiliki permasalahan dalam minat untuk melakukan pengungkapan kegiatan CSR dalam laporan tahunannya, atau perusahaan telat dalam pengungkapan laporan tahunan (tertunda satu tahun) sehingga sampel yang didapatkan hanya setengah dari populasi.

\section{Saran}

Beberapa saran yang peneliti ajukan adalah:

1. Peneliti selanjutnya dapat menambah variabel independen sehingga dapat merepresentasikan $78,5 \%$ varian variable Abnormal Return dijelaskan oleh varian variabel lain yang tidak diteliti.

2. Peneliti selanjutnya dapat mencoba mengaplikasikan penelitian terkait Abnormal Return di industri yang memiliki populasi yang lebih besar.

3. Peneliti dapat memperpanjang periode jendela dalam penelitian, sehingga hasil penelitian dapat lebih merepresentasikan kondisi pasar sesungguhnya 


\section{DAFTAR PUSTAKA}

(2012, oktober 26). Retrieved from Djarumfoundation.org:

http://www.djarumfoundation.org/aktivitas/detail_kegiatan/193/3/menanam-trembesi1350-km-merak---banyuwangi

Chandra, W. (2018, maret 31). Retrieved from Mongabay.co.id: http://www.mongabay.co.id/2018/03/31/masyarakat-pesisir-sulsel-makin-sulit-airkenapa/

Cheng, M., \& Christiawan, Y. J. (2011). Pengaruh Pengungkapan Corporate Social Responsibility Terhadap Abnormal Return. JURNAL AKUNTANSI DAN KEUANGAN, VOL. 13, NO. 1,.

Crowther, D., \& Aras, G. (2008). Corporate Social Responsibility. London: Forum Press. dni. (2016, juni 21). okezone.com. Retrieved from okezone.com: https://economy.okezone.com/read/2016/06/21/20/1420940/perlambatan-ekonomiglobal-ancam-investasi-indonesia

Faiza, F. (2017, juni 26). Retrieved from Medium.com: https://medium.com/faizafauziah/puntung-rokok-mungkin-benda-yang-kecil-namuntidak-berarti-sampah-puntung-rokok-merupakan-masalah-e733e6156386

Gray, R., Kouhy, R., \& Lavers, S. (1995). Constructing a research database of social and environmental reporting by UK companies. Accounting, Auditing and Accountability Journal, Vol 8 No 2, 78.

Greenpeace. (2016, maret 18). Retrieved from Greenpeace.org: http://www.greenpeace.org/seasia/id/press/releases/Laporan-Greenpeace-SelainMerusak-Lingkungan-Industri-Batubara-Melukai-Perekonomian-Indonesia/ Hartono, J. (2017). Teori Portofolio dan Analisis Investasi. Yogyakarta: BPFE. 
Husnan, S. (2005). Dasar-Dasar Teori Portofolio dan Analisis Sekuritas. Yogyakarta: UPP AMP YKPN.

Primus, J. (2015, Desember 18). Kompas.com. Retrieved from https://ekonomi.kompas.com/read/2015/12/18/155455926/Penting.Laporan.Keberlanjut an.Perusahaan.sebagai.Kewajiban

Qodriana, E. L. (2017). Akuntansi Lingkungan Kajian Penerapan. Simki-Economic Vol. 01 No. 03.

Rahardjo, a. (2012, agustus 8). Retrieved from Republika.co.id: http://www.republika.co.id/berita/nasional/lingkungan/12/08/07/m8e1ez-70-persenkerusakan-hutan-akibat-tambang

Restuti, M. D., \& Nathaniel, C. (2012). Pengaruh Pengungkapan Corporate Social Responsibility Terhdapat Earning Response Coeficient. Jurnal Dinamika Manajemen Vol. 3, No. 1,.

Yulia, V. I. (2013). Pengaruh Pengungkapan Corporate Social Responsibility Terhadap Abnormal Return . Jurnal Ilmu \& Riset Akuntansi Vol. 2 No. 3. 